\title{
'I Am Not A Foreigner Anymore': A Micro-Sociological Study Of The Experiences Of Brazilian Futsal Players In European Leagues
}

\author{
Paul Dimeo \\ Carlos Henrique de Vasconcellos Ribeiro **
}

\begin{abstract}
This paper represents the first stage of a longer term study of sport and migration. It focuses on Brazilian futsal players who have left their country of origin to play in Europe. Futsal is an indoor game with 5 players in each team. In some European countries, such as Spain and Portugal, it is a popular form of entertainment that is sufficiently commercialised to sustain full time professional players. Brazilian players are assigned stereotypical virtues of skilful styles of play. We interviewed XX players when they returned to Brazil for vacations. The focus of the questions were on three key themes: adaptation to the new country in social and sporting terms, questions of national identity, and some general questions about their attitudes and plans. The answers provided suggested migration has broadly turned out to be a positive experience, but the respondents make similar comments about their sense of 'otherness', their relationship with 'home' and their understanding of exile. From this point, we suggest that responses can only really be understood through a discourse theory framework of interpretation - they reveal the limitations of exile discourse rather than any inherent truth of their experience.
\end{abstract}

Keywords: Migration. Sports Futsal. Social Studies.

\section{INTRODUCTION}

Sport is one of the most salient ways in which individuals can move from one country to another to pursue their professional ambitions. In one sense, this reflects the perceived potential within sport to overcome social barriers and lead to wealth and success within a few years, the lifting out of the ghetto theory of sport. Arguably, this 'ultra-meritocracy' thesis has mostly been discussed with reference to African-Americans who pursue careers in basketball, baseball and gridiron in order to escape inner-city poverty (HOBERMAN, 1998). In a second sense, though, sports migration provides a microcosm of the enhanced flows of populations across national boundaries as globalisation processes have quickened in the past 20-30 years (XX).

Sports migration has a number of unique characteristics, some of which have been identified in previous research. The recent commercialisation and commodification of football has increased the flow of talent from the football industry 'periphery' to the

\footnotetext{
* Professor Doutor. Department Sports Studies. University of Stirling. Scotland, UK. E-mail: paul.dimeo@stir.ac.uk

** Professor Doutor na Área das Ciências da Saúde. Centro Universitário Augusto Motta (UNISUAM).

Rio de Janeiro, RJ, Brasil. E-mail: c.henriqueribeiro@ig.com.br
} 
'core'. The highly lucrative leagues of Western Europe attract players from other global regions. A number of scholars have explored the economic and social imbalances inherent in this process, suggesting that this is a form of neo-colonial exploitation. In a structural sense, the notion of 'asset stripping' can be applied since the best players are taken from their homeland and little return investment is made. However, the rewards available to these players have allowed some, such as George Weah and Romario, to establish charities and football academies in their respective countries.

Some features of sports migration are often overlooked though. One example is the host of players who struggle to make a success of their opportunities. If they fail abroad they must return home in disgrace. A second element is the emotional struggle faced by players and their families that echo identity issues faced by first and second generation migrants more generally. Not only do people feel dislocated, may face prejudiced stereotypes, but have to make very difficult decisions about how to develop a sense of home. Whether a success or failure however, many feel that the option to return is no longer available, as not only have they lost some social networking at home but they would be ashamed of the disappointing outcome of their émigré experience. Previous research, including a study of European return migration, has suggested that the longer a migrant stays in a country the less likely they are to return, and the if the economic rewards are higher in the new country return will be accompanied by dissatisfaction and reintegration problems (DUSTMANN, et a.l 1996).

\section{METHODOLOGICAL AND THEMATIC APPROACH}

A number of studies of a journalistic or biographical nature have shown the importance of football in Brazil and the impact Brazilian players have had on world football (BELLOS, ...). Inevitably most of the attention within these works has focused on players who established themselves on the international stage. That said, a few examples show that Brazilian players do not always find success when they migrate. Some football agents find it easy to play on the stereotype of Brazilian football talent and so sell players who are not quite good enough to unsuspecting clubs needing an ‘attraction' (BELLOS, 2002). 
Developing a framework for understanding Brazilian football migration is not as simple as media-based superficial narratives suggest. Thousands of young boys are desperate for the opportunity to play professional knowing full well that the best ones must migrate - the Brazilian Dream necessitates a physical and emotional journey, a reconsideration of their nationality, a divorce from their own way of life, and separation from family and friends. And yet, even for those players who do not reach the heights of success in Europe, the very fact that they played in that continent will give them respect back in Brazil and a great deal more economic benefit (BELLOS, 2002).

The cost to Brazilian football is the shame of having many of the world's best players but a league system struggling for quality on the field and for economic infrastructure off it. On the other side of this 'two-way' system are the players themselves and the 'host society' within which they end up playing.

The 'nexus' of the model - the focal point for developing sociological and cultural understanding of the experience of migration - has to be the players themselves. This study set out to interview football players who have migrated to Europe at a lower level of the sport - indeed, they play the indoor sport futsal that attracts large crowds in certain European countries. This offers some limited from of celebrity, economic security and the reputation for being a talented player. Futsal is not played in every footballplaying country and is considered a less sophisticated and interesting sport. However, there are some signs of its importance in specific countries.

Most of our interviewees play in Portugal where investment in futsal has increased over the past few years, so much so that the country will host the 2007 UEFA Futsal Championship. Almost every one of the matches in this tournament will be broadcast live across Europe on the channel Eurosport. Attendance levels for matches are expected to be $3-4,000$.

We conducted recorded interviews with players when they returned to Brazil during season breaks. The interviews focused on specific issues and offered the chance to consider in detail the varying experiences and reflections of specific players. Of course, they do not offer the potential for revealing the ethnographic context within which these experiences are to be found. The emphasis of the study is on what happens to the migrant player rather than the organisational milieu of football or futsal. 


\section{THE PROCESS OF MOVING}

The opportunities that arise for sport migration are developed through a variety of mechanism. Classically, a scout from a team in the host society would be looking for talent in specific regions. However, he would probably rely upon local talent spotters and agents to provide 'leads'. Between the local representative and the official scout, a trial would be arranged so that the club manager would be able to judge the players' ability and potential.

The experience of our respondents was different, perhaps because futsal is a less organised in international structural terms. One player, Fabio, said:

I was invited by a friend. He was playing there and asked if I want to play in Portugal and I accepted immediately. I was playing for a regular club in Rio de Janeiro and the offer was very good.

\section{Similarly, Danilo Mauro da Fonseca said:}

When I was playing for Vasco da Gama, one of vice-presidents asked me if I wanted to play in Portugal, and I accepted immediately. He wanted two Brazilian players and he has connections there, because he is from a Portuguese family. So it was his connections and their friends that made me go there.

And family contacts were central to the process for Rodrigo de Freitas Rodrigues:

My uncle got the things done, because he is a National futsal player in Spain. He plays in National team, and he helps me in everything I need in Europe. Everything I do I ask him what he thinks about. All the contracts, the agents and players I ask his opinion. I want to follow him, and I think he did the best in his career.

\section{ADJUSTING TO THE NEW LIFE}

Most accounts of football and migration assume a reasonably easy transition phase, unless there are some obvious problems. The public image of the football player is very much focused on his success rates on the field of play, while his private life and emotions are rarely discussed. We asked the futsal players about the challenges they faced in their new environment. The first question was about lifestyle. 
Fabio responded by saying:

I had a hard time there. It was my first time out of Brazil. Everything is different here and, the culture is different too. I didn't have good moments at first, because I had to do all the things by myself. Living alone is tough, but now I start to getting used to do it.

Da Fonseca had been in Portugal for 2 years by the time of this interview, and was beginning to feel a greater sense of affiliation with his new home. He emphasised many positive aspects of his experience, despite problems in the first few months of acculturation:

I have some problems in the beginning. The Portuguese language is different from Brazil. They speak no slang and sometimes it is difficult to understand them. I came from Rio and some words don't exist there. In general, I don't like the food. They only eat rice, potatoes and codfish. I like beans and rice. The city is small and it takes one hour and half to arrive in Porto, the biggest city in the area. I still don't know Lisboa, because the agent did not take us there. The city is quiet and in the beginning I had problems to get used to this situation. But, as you know, we have to get used to. I am playing in Portugal since I was 18, so I am going to my third season. I was 18 when I arrived there and I feel comfortable nowadays. In Portugal I was invited to make money that I cannot make in Brazil. They pay me three times more than in Brazil and they still pay my bills. My rent, and my laundry, and the groceries are included in my contract. So, I can save money to send to my family in Brazil, and I can keep some money with me.

Finally, a similar theme came out from an interview with the player Soneca, who was 21 years old when we interviewed him:

The adaptation was very hard. I suffer at least four months to get used with life and habits. I am a family person, and I got many problems there. I just trained bad or played not well I start to become sad. You know, I have no family there to support you, and the feelings to stay alone are horrible. I live in a small town and each game it seems all the town comes to see you playing. The city breaths football and I feel like the king when we win. 
Most respondents reflected upon their time in Europe in a similar way. They had struggle at first to adapt to their new life - feeling isolated and culturally detached. Yet, they realised the economic rewards and social status would offer adequate return for their temporary discomforts.

\section{NATIONAL IDENTITY AND OPPORTUNISM}

As noted in a recent Politikon paper:

Football migration also evokes deeper questions of nationality and statehood, which relate in a crucial way to the manner in which sport in general is a proxy domain for international political interaction, and through which sport assumes functions of modulating national identities (see for instance GRAINGER, 2006).

It is intriguing that none of the respondents reported on facing problems with the host society: questioning of their ethnicity or outright racism. The cultural ties between Portugal and Brazil, forged through centuries of colonialism, perhaps lie behind this partial acceptance. Certainly, players like the 20 year-old Fabio, have no problem desiring Portuguese nationality:

My first goal is to play for the Portugal National team. In Brazil there are a million players fighting for a vacancy in the national team. In Portugal there are a hundred fighting for the same wish. The club has already offered me a three years contract, but I declined. I don't want to. I prefer to assign a new contract every year so as to get better financial conditions. My situation is the follow: I'm trying to get the "Equality Certification". This certification you can get when you stay there for more than three years in Portugal. Then, I can play for the National team, but not for other European club. So, if I stay there for four years, I can get the "Sport Visa". It can give me a European passport with no agents or someone else. I just have to go to Embassy ask for it". This visa can give the opportunity to travel abroad in Europe, and I can sign contracts with different clubs. Portugal is the door to Europe for our Brazilians. 
Da Fonseca shared his point of view: "When I get my European visa, it will open many doors to me in Europe. It is a dream to become true. I can play in any club in Europe, mainly in Spain. Spain has the best futsal in the world, and I want to play there".

Ivan Silva is a Brazilian player who moved the Portuguese futsal before the recent upsurge in interest, and has now been there 12 years. He took the opportunity to play for the Portugal national team, yet unlike his younger compatriots, felt the emotional pull of Brazil still hung heavy:

It was great, because I had never had an opportunity to play for Brazilian National team. Playing for any National team is great, because you grow as a professional.

[...]

I've already played 4 friendly games and 2 officials' ones. It was in 2000 in Guatemala, and the Lusofonia games in Macau, 2006. The missing I felt happened when the Brazilian anthem played. The hart beat in pain, because in that moment I realised I'm Brazilian, but I was playing for another country. Since the game started, it was not the hart in charge anymore, but the mind of a $100 \%$ professional. Time after time, I start to respect and love a country. It includes my team mates. All of them accepted me as a sun, and in Brazil it was not possible.

[...]

First of all, the opportunity to represent a National team. It was unique opportunity in life, and it was impossible to denied, because this opportunity is the highest step of any player. In personal terms, it was a dream to play in a futsal world championship. So I took my chance, and I left behind all the things. I've been played for Portugal for 7 years already, and it is a huge proud.

Finally in this section, a comment from 25 year old William Manuel Ferreira, who also saw the route to personal glory being through full assimilation:

My goals are starting a business in Brazil and buying an apartment. In Portugal, I got my first step. It was playing in the first League. I also wanted to get my Equality Certification. It allows me to play for any club in Portugal and I am not getting any vacancy. In fact, I am not a foreigner anymore; they can count me as a Portuguese player. If I get married in Portugal I can get faster those documents, but I prefer not try to. More fours years, and I can get the Portuguese Visa. 


\section{CONCLUSION}

This paper is a first attempt to address issues of migration in the lived experience of Brazilian futsal players. We have argued that the essentialised versions of Brazilian style, combined with the structural opportunities of football as occupation, mean that this form of migration differs from the commonly understood patterns of labour migration.

There are some similarities, notably the economic power of the core states that draw migrants seeking higher levels of social and financial reward. Not only is Brazilian football migration different to generic migrations, but it also contrasts with other forms of sporting migration. Players do not need to go abroad to develop their skills; but many thousands of aspiring young players see the fields of Europe as the place for living out the 'Brazilian dream'. In other words, they need to take their skills abroad in order to prove their value.

"Eu não sou mais um estrangeiro": abordagem sociológica da experiência de jogadores brasileiros de futsal em ligas européias

RESUMO: Este estudo representa uma parte de uma linha de pesquisa que investiga as relações entre Esporte e Migração. Focamos nossa investigação em jogadores brasileiros de futsal que atuam em ligas européias, principalmente em países que mantém ligas profissionais de destaque, como Portugal e Espanha. Abordamos aqui as características por vezes estereotipadas da forma brasileira de jogar, com suas habilidades e atuação em quadras estrangeiras. Estas características com relação as suas performances acabam por servir tanto aos jogadores quanto aos clubes que os contratam alimentando o interesse dos torcedores. Entrevistamos 20 jogadores brasileiros de futsal quando estes estavam em férias no Brasil, em suas cidades-natais. Focamos nosso trabalho em três questões: a) adaptação ao novo país em relação à vida social e dentro das quadras; b) questões sobre identidade, focando na possível aquisição de uma nova cidadania; c) questões sobre ordem familiar e independência financeira. As análises das entrevistas apontam para um dado positivo da experiência em países no estrangeiro, principalmente sobre a aquisição de um "estilo" europeu de jogar futsal. Encontrarmos também a questão do não-pertencimento, seus vínculos afetivos deixados no Brasil e a tentativa de formar uma poupança financeira voltada para os anos de aposentadoria. Estudos futuros podem revelar como a relação entre esporte e migração atinge uma parcela significativa de atletas brasileiros e suas conseqüências em termos sociais, econômicos e pessoais para os que partem para as quadras estrangeiras.

Palavras-chave: Migração. Esportes. Sociologia

\section{"Yo no soy más un extranjero": abordaje sociológico de la experiência de jugadores brasileños de futsal en ligas europeas}

RESÚMEN: Este estúdio representa una parte de una línea de pesquisa que averigua las relaciones entre Deporte y Migración. Concentramos nuestra investigación en jugadores brasileños de futsal que actúan en ligas europeas, principalmente en países que mantienen ligas profisionales de destaque, como Portugal y España. Abordamos aquí las características por veces esteriotipadas de la manera brasileña de jugar, con sus habilidades y actuación en canchas 
extranjeras. Estas características con relación a sus performances acaban por servir tanto a los jugadores cuanto a los clubes que los contratan alimentando el interes de los hinchas. Entrevistamos a 20 jugadores brasileños de futsal cuando estos estaban de vacaciones en Brasil, en sus ciudades-natales. Concentramos nuestro trabajo en tres cuestiones: a) adaptación al nuevo país con relación a la vida social y dentro da las canchas; b) cuestiones acerca de la identidad, particularmente la posible adquisición de una nueva ciudadanía; c) cuestiones acerca del orden familiar e independência financiera. Los análisis de las entrevistas apuntan para un dato positivo de experiencia en países extranjeros, principalmente acerca de la adquisición de un "estilo" europeo de jugar futsal. Encontramos también la cuestión del no-pertenecer, sus vínculos afectivos dejados en Brasil y el intento de formar un ahorro financiero dirigido para los años de jubilación. Estúdios futuros pueden revelar como la relación entre deporte y migración alcanza una parcela significativa de atletas brasileños y sus consecuencias en términos sociales, económicos y personales para a los que parten para las canchas extranjeras.

Palabras clave: Migración. Deportes. Estudos Sociales.

\section{REFERENCES}

BELLOS, A. Fútbol: the Brazilian Way of Life, London: Bloomsbury, 2002.

DUSTMANN, C; BENTOLILA, S.; FAINI, R. Return Migration: The European

Experience. Economic Policy, Munich, v. 11, n. 22, p. 213-250, 1996.

CNN 'Kuranyi grabs Germany's equalizer', CNN.com, 8 Sep. 2004. Disponível em: $<$ http://www.cnn.com/2004/SPORT/football/09/08/germany.friendly/index.html?eref=sit esearch.> Acesso em: 10 Jan. 2007

FALCOUS, M.; MAGUIRE, J. Globetrotters and Local Heroes? Labor Migration, Basketball, and Local Identities'. Sociology of Sport Journal, Edmonton, v. 22, p.137$157,2005$.

MAGUIRE, J.. Sport Labor Migration Research Revisited. Journal of Sport \& Social Issues, Champaign, v. 28, n. 4, p. 477-482, 2004.

MARGER, M. N. Transnationalism or assimilation? Patterns of socio-political adaptation among Canadian business immigrants. Ethnic and Racial Studies, Dublin, v. 29, n. 5, p. 882-900, 2006.

Agradecimentos ao financiamento FAPERJ

Received on: 19.03.2008

Approved on: 16.02.2009 